\title{
THE FUTURE OF ISLAMIC LAW IN BRITISH COMMONWEALTH TERRITORIES IN AFRICA
}

\author{
J. N. D. ANDERSON*
}

\section{INTRODUCTION}

Two questions are not infrequently asked by those who approach the subject of the continued application of Islamic law in the emergent countries of Africa with a general idea of the nature of that law but a limited acquaintance with legal developments, during the last century or more, in the Middle East, the Indian subcontinent, and the dependent or formerly dependent territories of East and West Africa. The first concerns the practicability of maintaining a situation under which different members of the same national state are subject to different systems of law. Can a modern society, it is asked, long remain viable if its legal system enshrines an interpersonal conflict of laws? The second involves the very nature of Islamic law and the possibility of its adaptation to modern life. Can an authoritative law, which is regarded as firmly based on divine revelation, so adapt itself-or be adapted-as to enable it to resolve the typical conflicts of an industrial society?

\section{I}

\section{The Nature of IsLamic Law}

According to the classical theory of Islamic jurisprudence, the Sharīa, or divine law, was derived from four main sources: from the Qur'ân, as the ipsissima verba of Almighty God; from the Sunna or practice of the Prophet, as equally inspired in content if not in form, and as established by a multitude of traditions as to what he said, did, and allowed to be done; from the Ijmā or consensus of the doctors of the law, as yet another guarantee of the divine will; and from Qiyās, or the analogical deductions of the jurists from these primary sources. It is true that recent research has demonstrated that Islamic law as we know it was not, for the most part, deduced directly from the sacred sources but rather evolved by a succession of jurists who worked through the customary law and administrative practice of the first century of the Hijra, adopting, adapting, and discarding such law and practice on the basis of Islamic norms. ${ }^{1}$ But this is less significant for our immediate purpose than the fact that the overwhelmingly greater part of the law was based even in the classical theory on the analogical deductions of the jurists, as authenticated, in some cases, by an alleged consensus. For the Qur'an includes comparatively few verses of directly

*B.A. I930, LL.B. 1931, M.A. 1934, LL.D. 1955, M.B.E. 1943, O.B.E. 1945. Professor of Oriental Laws and Director of the Institute of Advanced Legal Studies, University of London. Author, Istamme LAW IN Africa (I954); IsLAMIC LAW IN THE MODERN WORLD (I959); and contributor of numerous articles on this subject.

${ }^{1}$ Compare, in particular, Joseph Schacht, The Origins of Muhasamadan Jurisprudence (1950). 
legal significance, while the vast majority of traditions attributed to the Prophet are of distinctly dubious authenticity even by Muslim standards-quite apart from the devastating criticism to which they have been subjected by Western scholars. ${ }^{2}$

Until the end of the third century of the Hijra, indeed, any adequately qualified jurist was regarded as entitled to go back to the original sources of the law and to make his own deductions. It was only with the crystallization of the different "schools" of law and the consequent elaboration of the doctrine of consensus that the "door of independent deduction" came to be regarded as, in practice, closed." Even so, the Islamic law was very far from being one and indivisible. Instead, there were a variety of "orthodox" schools, of which only four ultimately survived; there were a number of "heterodox" schools formed by those who are commonly regarded as sectaries; and there was a multitude of variant opinions held by different jurists within the recognized schools, professed by leaders of extinct schools, or attributed to authorities who preceded their formation.

Not only so, but in the early decades of the Muslim conquests the subjugated peoples were largely left to their own laws and their own legal institutions, while the needs of their Arab conquerors were met by the appointment of an official who can be regarded as a sort of legal secretary to the governor of the province. In course of time, however, the office of Qâd̦i or judge came to be filled by those pious experts through whose efforts the Islamic law came into being; and their judicial discretion became more and more rigidly bound by its requirements. But while the resultant law was all inclusive in its scope, and while in theory it was all equally authoritative, it is undeniable that some parts were more jealously regarded and more meticulously applied than were others.

This is attributable in part to the fact that this law was evolved as an annunciation of theoretical propositions and hypothetical distinctions largely divorced from everyday practice (for the rigid prohibition of fixed rates of interest or of speculative contracts was far removed from the actual life of the markets); in part to the circumstance that no Muslim ruler seems to have been content to leave the maintenance of public order and the administration of criminal justice exclusively to those courts which were tied, both in matters of procedure and substantive law, to its meticulous requirements; and in part to the fact that the constitutional law was largely an ex post facto rationalization of historical developments. As a consequence, other jurisdictions in fact grew up from an early date alongside that of the Qädis, and it was chiefly in the sphere of family relations and the law of succession-together with civil wrongs, basic contracts, and parts of the criminal law-that the Shari'a was meticulously applied. For it has always been the law of marriage and succession

\footnotetext{
${ }^{2}$ Here, again, Professor "Schacht must be regarded as the leading authority. Cf. ScHAcur, op. cit. supra note I.

${ }^{3}$ In theory, it is true, the possibility of a jurist appearing who was qualified to exercise the right of independent deduction was not excluded, but the necessary qualifications were put almost impossibly high.
} 
which has been regarded by Muslims as most intimately connected with the practice of their religion.

Yet, at the same time, the Sharía was universally acclaimed as the only law, to which ruler and people were alike-and uniquely-subject; and those customary practices and administrative regulations which were enforced by officials, police, or merchants were never accorded any comparable status. As for the Shari $\bar{i}^{-}$a itself, this was largely moribund; for in each of the schools a dominant doctrine on most points had slowly asserted itself and was regarded as binding on future generations. The law was not entirely static, because new situations would inevitably arise; but for the most part legal scholarship found its expression in the compilation of endless commentaries and glosses on previous commentaries and glosses.

II

\section{Law Reform in IsLamic Countries}

Such was the position throughout the vast majority of the Muslim world until little more than a century ago. But since then major developments have taken place almost everywhere. In the Ottoman Empire these started with the Tanzimait reforms, and took the form of the promulgation of frankly secular codes of Western origin-such as the Commercial Code in $185^{\circ}$ and the Penal Code in $185^{8}$-and the establishment of a secular (Nizämiya) system of courts to apply them. Henceforth the Sharīa courts were to be confined to the law of family relations and succession in their widest connotation. But it is noteworthy that whereas the resultant dichotomy between the courts was complete, the dichotomy in the law they applied was mitigated by the fact that the Ottoman Law of Obligations (the Majalla) represented a codification of precepts drawn not from Western law but from the Sharīa. In Egypt, too, which had attained juridical independence under the Khedive Ismāinl, a similar dichotomy was effected in the courts and-less completely-in the law they were to apply. For it is noteworthy that, at this stage, it was generally considered preferable to leave the Shari'a intact and immutable, even if this meant displacing it in one particular after another by a law of wholly alien inspiration, rather than to allow any profane meddling with its sacred precepts.

In "British" India, events took a course which was in some respects similar and in others different. As in the Ottoman Empire and Egypt, the Sharīa law-as applied under the Moghul Emperors and the East India Company-was progressively displaced by a series of enactments such as the Indian Penal Code, Evidence Act, Contract Act, and the Transfer of Property Act. The Shari'a law became largely limited to matters of family relations and succession in respect of Muslim litigants. Unlike the Ottoman Empire and Egypt, however, there was no corresponding dichotomy in the courts. Instead, the same courts administered whatever law was applicable in any particular case.

More recently, there have been further developments. Right up till IgI5 the 
Shari'a law was administered throughout the Ottoman Empire in the traditional way, with the dominant view in the Hanafi school in unique ascendance; but in that year the pressure of social conditions made reforms in the Sharía law itself inevitable. The dike thus breached, a series of most interesting reforms have been introduced-first in Turkey and then in one after another of the Arab countries-by which the law of family relations and succession has been brought much more closely into line with the requirements of modern life. But it is important to observe that this has been done, not by the earlier expedient of displacing the Shari'a in favor of a codified law of Western inspiration, but rather by a number of ingenious expedients by which reforms have been effected in the sacred law itself as administered by the courts without-in theory, at least-affecting its Islamic character and authority. Some of these expedients will demand more detailed notice later; but for the present it is enough to remark that they have resulted in a partial-or sometimes comparatively complete-codification of the relevant precepts. And it should be observed that much the same phenomenon appeared in British India in the Dissolution of Muslim Marriages Act, I939, and-more recently-in the Pakistan Muslim Family Laws Ordinance, 196r. ${ }^{4}$

Inevitably, however, these significant developments in the law of personal status have led to a new attitude towards the rest of the law. Gone is the day when it was considered sacrilegious to tamper in any way with the sacred law, even if this meant putting it on one side in practice in favor of laws of Western inspiration. Instead there has been an increasing demand in Middle East countries to make a wider use of their own cultural heritage, together with an insistence-on the part of a somewhat vocal minority - that an adequate code for all the requirements of modern life could be derived from the Shari'a alone, provided only that its riches were exploited in a sufficiently radical manner. New Civil Codes have, in fact, been promulgated in a number of Arab countries; but while considerable publicity has been given to their debt to the Islamic sources, it is noteworthy that in practice the Egyptian Civil Code of 1948 (which has been largely adopted in Syria and Libya) remains substantially French in its origin, while the Iraq Civil Code of 1953 represents a fusion between the Egyptian Civil Code and the Majalla.

Yet a further consequence of the progressive codification of the specifically "Islamic" law which is still applied in most Middle Eastern countries-in so far as Muslim litigants are concerned-in all matters of family relations and succession, is an increasing tendency towards the unification of the courts. The sharp dichotomy which emerged about a century ago between the old Sharía courts and the new secular courts was powerfully reinforced and perpetuated by the essentially different training required by those who presided and practiced in each. Almost from the first, the secular courts were staffed by personnel educated in a modern law school of the Western type, while the judges and advocates of the Shar'ta courts, who still

"Gazette of Pakistan Extraordinary, March 2, 196r. 
needed to extract the dominant Hanafī (or Mālikī) opinion from a plethora of medieval texts, could only be drawn from those trained in the traditional manner. But as soon as the family law, too, came to be codified, the situation completely changed; for it now became almost as easy for the graduates of a modern law school to administer the law of family relationships as to apply the Commercial Code or the Penal Code.

As a consequence, the courts have been unified in recent years in both Egypt and Tunisia; ${ }^{5}$ and although the fact that the existing personnel of the Shari'a courts have for the most part been absorbed in the national courts has meant that little change has up till now been effected, it seems clear that in the future no more judges or advocates will be recruited from those trained in the traditional way. And it appears likely that the increasing pressures of nationalism and bureaucracy will lead other Arab countries to contemplate a similar unification of their courts.

Yet the fact remains that, in almost all these countries, a different law of family relations is still applied according to the religion of the litigants. In parts of the Arabian peninsula, it is true, no law other than the law of Islam is given any official recognition; in Turkey, the Shari'a was abandoned in I926 in favor of the Swiss law of marriage and succession; and in Tunisia the Jewish community has voluntarily accepted the Law of Personal Status, r956. But in most of the Arab countries no attempt has been $\operatorname{made}^{6}$ to unify the law of marriage and divorce, or even, in some countries, the law of testate and intestate succession. So the law properly applicable to the litigants, whether codified or not, is still applied either by the appropriate community courts or by the unified national courts which have taken their place in Egypt. And this is also true, of course, in India and Pakistan, where the personal or religious law of the litigants is still applied in all such matters.

\section{III}

\section{Islamic Law in British Africa}

\section{A. The Typical Hierarchy of Legal Norms}

When we turn to those countries in East and West Africa which have known British rule, we find a situation which-for all its differences-is not wildly dissimilar. It is true that some of these countries were conquered or ceded, while others may be regarded as having been settled. But in every case it has been recognized that the British settlers and officials have brought their own law with them, in so far as local circumstances may permit, while the indigenous populations have retained their existing law-except where this was regarded as contrary to natural justice, has been specifically replaced by legislation, or has been displaced in practice by the more sophisticated immigrant system. Thus the relevant Order in Council commonly provides for a Court of Record with "full jurisdiction, civil and criminal, over all

\footnotetext{
The same intention has still more recently been announced in Iraq.
}

- It is true, however, that this has at times been discussed. 
persons and all matters," to be exercised in accordance with the "common law, the doctrines of equity and statutes of general application in force in England" on a specified date. ${ }^{7}$ At the same time, however, it is explicitly laid down that this imported law "shall be in force ... so far only as the circumstances of the Territory and its inhabitants ... permit, and subject to such qualifications as local circumstances may render necessary"; $;$ and it is also provided that, ${ }^{9}$

In all cases, civil and criminal, to which natives are parties, every Court shall (a) be guided by native law so far as it is applicable and is not repugnant to justice and morality or inconsistent with any Order in Council or Ordinance ...; and (b) decide all such cases according to substantial justice without undue regard to technicalities of procedure and without undue delay.

The reference to ordinance law points, of course, to the major source of legal development in each of these countries, whether dependent or independent. For the overwhelming majority of changes in the law has been introduced everywhere by local legislation, whether this was promulgated by the Governor, by the Governor in Council, by the democratic procedures of a Legislative Council or House of Assembly, or by the procedures suitable to an independent country.

But all this primarily concerns the system of courts of directly British inspiration-i.e., the magistrates' courts, the Supreme or High Court, and the different courts of appeal. The overwhelmingly greater part of all litigation which concerns Africans, however, is conducted in a system of courts which are termed "native," "local," "African" or "customary," according to the territory concerned. Provision for these has in each case been made by local ordinances, under which a whole hierarchy of such courts has been set up. Sometimes, as in Kenya, there is no link whatever between the "British" and the "African" systems of courts; sometimes, as in Tanganyika, an exceedingly tenuous link has been forged; and sometimes, as in Nigeria, the two systems have been fully integrated.

Broadly speaking, moreover, the law administered by the "native" courts is precisely the "native law and custom" to which reference has already been made. As a consequence, their jurisdiction is commonly limited to "natives"-a term which is somewhat differently defined from territory to territory-while provision is sometimes made for including such immigrants as have adopted the manner of life of the indigenous inhabitants, or for excluding-in some respects-such natives as may have abandoned that manner of life. In addition, the native courts regularly enforce local legislation, in the form of Native Authority Orders, and even territorial legislation, in the form of such Ordinances, or parts of Ordinances, as they have been specifically empowered to apply.

${ }^{7}$ However, it should be observed that in several of the East African colonies and protectorates provision is made for jurisdiction to be exercised in conformity with the Civil and Criminal Procedure Codes of India, and other Indian Acts, and only thereafter in accordance with the Common Law.

${ }^{8}$ See, e.g., Tanganyika Order in Council, I920, $\$ 7$.

Id. $\$ 24$. 
B. The Place of Islamic Law

But where, it may pertinently be asked, does the Islamic law fit into this picture? And how, and to what degree, does it come to be applied in East and West Africa? The best illustration, perhaps, is provided by the way in which Roman-Dutch law originally developed. Here the process seems to have been somewhat as follows: In those parts of Northern Europe where this system came into being, a customary law of Germanic origin previously prevailed. Then, from a certain date, the rediscovered Roman law began to infiltrate, chiefly through the influence of the Church and the universities. Still later, the Roman law was officially "received." But it never, in reality, succeeded in completely displacing the existing customary law: instead, it became fused with the existing law, and a sort of amalgam of the two systems evolved.

Almost exactly the same sort of process has taken place in regard to customary law and the Islamic law in the different parts of Africa. Islam has penetrated, or is still penetrating, many parts of the continent, and the influence of Islamic law has been widely spread, superficially at least, through Muslim merchants and members of the religious orders. As a result the indigenous customary law has been leavened, in certain areas, by Islamic principles and precepts-to a degree which differs widely, of course, from place to place. In certain areas, moreover, it has been virtually displaced by the law of Islam, particularly where a native ruler has attempted to impose this law upon his people. But nowhere in tropical Africa has the imposition been complete, for traces of the customary law survive even in the most rigidly Muslim areas.

\section{Ghana, Sierra Leone, Uganda, and Nyasaland}

British territories in Africa may, in fact, be divided into those in which the Islamic law and the customary law are treated as largely identical - or at least as an indistinguishable amalgam-and those in which Islamic law is regarded as a third, distinct system, alongside the English and the indigenous law. Examples of the former may be found in Ghana, Sierra Leone, Uganda, and Nyasaland-except, that is, within the scope of certain ordinances which provide for the Islamic law to be applied, as such, in these territories in certain prescribed matters: e.g., the Marriage of Mohammedans Ordinance, 1905, in Sierra Leone (but this applies only to the Colony of Freetown, not the Protectorate); the Marriage and Divorce of Mohammedans Ordinance, I906, in Uganda (but this excludes any provisions regarding succession); and the Asiatics Marriage and Divorce Ordinance, 1929, in Nyasaland (but this, by definition, does not apply to indigenous Muslims). More surprisingly, Northern Nigeria-where the Islamic law was, until very recently, more extensively applied than anywhere else in Africa-fell within this category until the Native Courts Law and Moslem Court of Appeal Law, both of 1956, introduced for the first time an explicit distinction between the Islamic law and the customary law. 


\section{Somaliland, Kenya, and Zanzibar}

Examples of territories where the Islamic law is regarded as a third, distinct system, on the other hand, are provided by the former British Somaliland, Kenya, and Zanzibar. In Somaliland both Qäd̦is' courts and other subordinate courts co-exist, the one applying the Islamic and the other the customary law, each within fairly well-defined limits. In Kenya, again, Muslim courts are found, chiefly in the coastal Protectorate, alongside African tribunals, while there is also a Marriage and Divorce of Mohammedans Ordinance. In Zanzibar, on the other hand, Islamic law has been recognized as the "fundamental law" in the courts of His Highness the Sultan, although it has been very widely displaced by statute law in the form of the Sultan's Decrees; but even here provision has been made for the application of a minimum of customary law.

\section{The Gambia and Tanganyika}

Somewhere between these two categories fall the Gambia in the West and Tanganyika in the East. In the Gambia, the Mohammedan Law Recognition Ordinance, I905, made provision for the application of Islamic law to Muslims in the Colony of Bathurst in all matters of marriage, divorce, guardianship and succession, while subsequent legislation has set up a second Qäḑī's court, with similar jurisdiction, in the neighboring area of Kombo St. Mary. The Native Tribunal Ordinance, I933, which provides for the application of native law and custom throughout the Protectorate of the Gambia, also makes specific provision for the application of Islamic law in the Protectorate, in similar matters, where the parties are Muslims. The difference is that in the former courts Islamic law should be applied exclusively (although in reality the customary law, even there, in some respects prevails), while in the latter both the customary law and the Islamic law are officially applicable, and the result is usually a heterogeneous amalgam between the two, compounded according to the knowledge and inclination of the court concerned. And somewhat the same situation obtains in Tanganyika, for here the Islamic law is applied fairly extensively by certain other "local" courts, largely, in practice, as a matter of discretion. ${ }^{10}$

\section{Islamic Law Other Than Family Law, Succession, and Waqf}

\section{East Africa}

But what is even more relevant to our present context is to determine to what extent the Islamic law is applied as such outside the basic sphere of family relations and succession or, in East Africa only, the law of wagf." ${ }^{11}$ Here the two territories which leap to the mind are Zanzibar in the East and Northern Nigeria in the West. In Zanzibar the position is complicated by the existence of the "dual jurisdiction" of Her Britannic Majesty and His Highness the Sultan; for whereas, under the former

\footnotetext{
${ }^{10}$ Except, that is, within the scope of the Administration (Small Estates) (Amendment) Ordinance and the Asiatics (Marriage, Divorce and Succession) Ordinance, both of 1947 .

${ }^{11}$ It is noteworthy that the law of waqf is virtually unknown-in practice-in West Africa.
} 
the Islamic law is applied only in matters of family law, succession and waqf, ${ }^{12}$ under the latter the Islamic law, as we have seen, has been proclaimed as the "fundamental law."13 Even so, this fundamental law has been so extensively displaced by local legislation that only a residuum of Islamic law remains, chiefly in cases of tort, ${ }^{14}$ a very limited range of contracts, ${ }^{15}$ and questions of real property. ${ }^{16}$

Much the same can be said of the coastal "Protectorate" of Kenya, which is still officially part of the dominions of the Sultan of Zanzibar. The juristic basis for the application of Islamic law in Kenya still goes back, in our view, ${ }^{\mathbf{1 7}}$ to the Native Courts Regulations, 1897 , where it was provided that "native courts" (a term which at that time included both courts presided over by a European officer and courts presided over by a native authority) should "within the Mohammedan Coast region, or in dealing with Mohammedans, also be guided by, and have regard to, the general principles of the Law of Islam"-as well as being guided by, and having regard to, "any native laws and customs not opposed to natural morality and humanity."18 But again Islamic law is seldom applied today, even in the Protectorate, outside the law of the family, succession, and waqf, although cases of tort, contract, and real property in which this law is applicable still come before the courts. In the rest of Kenya such cases as occur are almost exclusively governed by the Mohammedan Marriage, Divorce and Succession Ordinance, I923, or the Waqf Commissioners Ordinance, $195^{10} .^{10}$

In Tanganyika the juristic basis for the application of Islamic law by the Liwalis and other local courts can, presumably, be found in the fact that parts of this territory were also originally under the jurisdiction of the Sultan of Zanzibar; that the Liwalis continued to apply this law under the German regime; and that the existing law must be regarded as having remained in force under the British administration and since independence, unless and until specifically replaced. Again, however, this means little more in practice than the application of Islamic law to Muslim litigants $^{20}$ in matters of family relations, succession, and waqf, although cases of tort, contract, and real property are also, no doubt, sometimes so decided. ${ }^{21}$

${ }^{15}$ Under Bombay Regulation 4 of $x 827, \$ 26$. This provides for the application-in default of any relevant statute-of the custom of the country, the law of the defendant, or justice, equity and good conscience. This Regulation became applicable to Zanzibar when the legislation of the Bombay Presidency was extended to that country.

${ }^{13} \mathrm{Cf}$. Courts Decree, 1923, $\$ 7$.

14 Although few such cases seem, in point of fact, to be heard in the Sultan's courts.

${ }^{10}$ Although the Contract Decree and the Transfer of Property Decree, both of 1917 , cover the greater part of the law of contract.

${ }_{10}$ These would fall to be decided according to Islamic law-in default of relevant legislation-even in the British courts, as the lex loci rei sitae. But a number of legislative enactments, in fact, cover much of the field. For the law of Zanzibar, see J. N. D. Anderson, Istamic Law in Africa 58-80 (r954).

${ }^{17}$ For a discussion of this controversial question, see id. at 82-84.

${ }^{18}$ Native Courts Regulations, I897, arts. 2 and 3.

${ }^{10}$ For the law of Kenya, see ANDERson, op. cit. supra note 16 , at $8 \mathrm{I}-\mathrm{I} 2 \mathrm{r}$.

${ }^{30}$ In matters of succession this is governed by the terms of the Administration (Small Estates) (Amendment) Ordinance, 1947, while in the case of immigrant Muslims the Asiatics (Marriage, Divorce and Succession) (Amendment) Ordinance, 1947, applies.

${ }^{21}$ For Tanganyika, see ANDERson, op. cit. supra note I6, at $122-47$. 
In Uganda, the application of Islamic law is virtually confined to the terms of the Marriage and Divorce of Mohammedans Ordinance, rgo6-except, perhaps, for an occasional concession to Muslim influence in the customary law of particular localities. $^{22}$ In Nyasaland, again, such concessions appear to be minimal, and Islamic law is not administered as such to any but Asian immigrants under the Asiatics (Marriage, Divorce and Succession) Ordinance, $1929 .{ }^{23}$

In the former British Somaliland Protectorate, on the other hand, Islamic law was everywhere applied in the Qādīis' courts in matters of marriage, divorce, succession, waqf, and so on, just as Somali customary law was applicable in other courts in questions of bride-wealth, adultery, insult, and a variety of other matters-on the juristic basis, presumably, that such was the law before the British came. The interrelation of Islamic law and Somali customary law in the life of the Somalis is, indeed, a fascinating study; but it would probably be true to say that outside the limited jurisdiction allotted to the Qădîs under the Subordinate Courts Ordinance, 1944, it is the Somali customary law-greatly influenced though this has been, down the centuries, by the law of Islam and of the Arabs-which emerges, in this point or that, from the sphere of family law (in its widest connotation) into the realm of contract, tort, or crime. ${ }^{24}$

\section{West Africa: Northern Nigeria}

When we turn to West Africa, we again find that in the Gambia, Ghana, and Sierra Leone, Islamic law is virtually confined to matters of family relations and succession-whether under the terms of some relevant ordinance ${ }^{25}$ or as the "native law and custom" of the area or community concerned. It is only in Nigeria -and there only in the Northern Region ${ }^{26}$ - that the law of Islam has been extensively applied in the spheres of criminal law, contract, tort, and procedure. Yet no statutory basis can be found for the application of Islamic law as such in Nigeria prior to 1956,57 other than the comprehensive umbrella of native law and custom. The fact remains, however, that up till 1959 the Islamic law was more extensively applied in Northern Nigeria than anywhere else in the world outside the Arabian peninsula or Afghanistan.

The reason for this phenomenon was, of course, historical. At the inception of the British Protectorate Lord Lugard found many of the Muslim emirates administering justice in a way conspicuously superior to the conditions which prevailed elsewhere; and their courts were not only permitted to continue, ${ }^{28}$ but allowed

${ }^{23}$ For Uganda, see id. at $148-61$. ${ }^{23}$ For Nyasaland, see id. at 162-70.

${ }^{34}$ E.g., in regard to the law of qasäma or häl. For Somaliland, cf. Anderson, op. cit. supra note 16 , at $40-57$.

${ }^{25}$ E.g., those mentioned supra, at 623-24.

${ }^{28}$ In the Eastern Region there are very few Muslims. And, although there are large numbers of Muslims in the Western Region and in Lagos, they pay scarcely any attention to Islamic law even in the sphere of family relations and succession, where the customary law still prevails.

${ }^{37}$ See supra p. 623.

${ }^{28}$ Except that the infliction of punishments such as lapidation and mutilation was forbidden, and that the method of execution was prescribed by law. 
to retain the coveted distinction of exercising the "power of life and death"29-i.e., trying capital offenses. The result was that jurisdiction, even in homicide cases, was divided between two sets of courts-the "British" and the "native"-each administering a wholly distinct system of law; for in the "British" courts the Nigeria Criminal Code represented a codified form of the common law, while in the Emirs' courts the Islamic law of the Mālikĩ school prevailed.

As a consequence, a Nigerian who committed a homicide might be tried under the one system or the other, ${ }^{30}$ including the appropriate law of evidence and procedure; and the resulting verdict and sentence might depend entirely on this initial circumstance. Not only so, but much might also depend on the religion of the accused and his victim; for in the native courts Muslim witnesses stood on a wholly different footing from non-Muslims, and the blood of a Muslim was regarded as of so much more value than that of an "unbeliever" that the death penalty-which in any case usually depended on the demand of the "heirs of blood"-could seldom be imposed where a Muslim had killed a Christian or a pagan.

This was obviously an impossible position in a country which was on the threshold of independence. It is true that most of the injustices which might have otherwise resulted from this system were in fact averted either on appeal or, more frequently, by the exercise of a British administrative officer's discretion to transfer a case from one court to another at any stage in the proceedings. But it was uncertain how far these safeguards would persist after independence; so the apprehensions of the considerable non-Muslim minority ${ }^{31}$ were eminently understandable.

It was in these circumstances that a Panel of Jurists, on which the writer had the honor to serve, was appointed by the Northern Nigerian Government in the summer of 1958. Our terms of reference were to consider, in the light of the legal and judicial systems obtaining in other parts of the world where Muslims and nonMuslims live side by side, whether it was possible to avoid conflicts of law between the three systems of law currently in force in Northern Nigeria (i.e., the English, the Islamic, and the customary law), and to make recommendations as to how this could be done. ${ }^{32}$

To this there was only one possible answer: that such conflicts were minimized in all other mixed communities by the fact that in such localities Islamic law is virtually confined, today, to the personal and family law of Muslim litigants. The major recommendations of the Panel were, therefore, that the Islamic law should be totally excluded from the sphere of criminal justice, whether substantive or procedural, by the promulgation of suitable codes; that it should remain applicable as

${ }^{20}$ The only other Commonwealth country in Africa where the courts of an indigenous ruler have such power is Zanzibar; but there the courts of His Highness the Sultan apply the same Penal Decree and are in fact staffed by the self-same judges as the courts of Her Britannic Majesty.

${ }^{30}$ This would, in fact, depend on a number of largely fortuitous circumstances. See Anderson, Conflict of Laws in North Nigeria: A New Start, 8 INT'L \& CoMp. L.Q. 442, 444 (I959).

${ }^{31}$ These are usually reckoned as about one-third of the total population of the Region.

"Cf. Anderson, supra note 30. See also Anderson, Return Visit to Nigeria: Judicial and Legal Developments in the Northern Region, I2 INT'L \& COMP. L.Q. 282 (1963). 
such only in the sphere of family relations and succession, in so far as Muslim litigants were concerned; and that it should also be applicable, where appropriate, either as the law under which some particular contract was in fact concluded or as the law of tort which was locally accepted as valid. And although these recommendations were far more drastic than had been expected-or, indeed, than anyone thought that local opinion would accept-the Northern Nigerian Government not only accepted them in principle but proceeded, in I959, to give them legislative effect.

This does not mean, of course, that no problems whatever remain in Northern Nigeria today in connection with the law which was formerly so extensively applied. Pressure of Muslim opinion secured the insertion, in the Northern Nigerian Penal Code, of sections penalizing anyone who, being of the Muslim faith, "drinks anything containing alcohol other than for a medicinal purpose"33 or anyone who, being subject to any native law or custom in which extramarital sexual intercourse is recognized as a criminal offense, indulges in such intercourse with one whom he (or she) knows or has reason to believe is not his (or her) lawful spouse. ${ }^{34}$ It is obviously possible that such provisions will be challenged as contrary to section 27 of the Nigeria (Constitution) Order in Council, 1960, which provides that a citizen of Nigeria shall not, by reason of his tribe or religion, be subjected to any law to which citizens of Nigeria from other tribes or religions are not made subject, but with an important proviso. ${ }^{35}$

Again, some confusion seems to prevail at present in regard to cases involving land; for the view that these are governed by customary ${ }^{30}$ rather than Islamic law is being increasingly challenged, particularly in matters of inheritance, by the Shari'a Court of Appeal. Yet again, the provision that the Shari'a Court of Appeal shall have jurisdiction "where the parties (whether they are Moslems or not) agree in writing that their case shall be dealt with in accordance with Moslem Law"37 might well lead to confusion if the parties to a case in which the Islamic law was not properly applicable should elect to have their case so decided.

\section{ConcLusion}

If we look at Commonwealth countries in Africa as a whole, it is clear that, today, Islamic law represents a very minor problem outside the sphere of family relations and succession-or, in East Africa, the law of waqf. In the law of contract there can be scant objection to its application, probably to an ever decreasing extent, as the law under which a particular contract was in fact concluded. In the field of tort there is little difficulty in reconciling Islamic concepts with English

\footnotetext{
${ }^{33}$ Sec. 403.

${ }^{84}$ Secs. 387 and 388 .

${ }^{35}$ The Nigerian (Constitution) Order in Council, 1960, $\$ 27(2)$ (d) provides: "Nothing in this section shall invalidate any law by reason only that the law ... imposes any disability or restriction or accords any privilege or advantage that, having regard to its nature and to special circumstances pertaining to the persons to whom it applies, is reasonably justifiable in a democratic society."

${ }^{30}$ That is, outside the scope of legislative enactments.

${ }^{37}$ Shari'a Court of Appeal Law, 1959, \& 12(e).
} 
principles, and the Islamic law of tort is in fact seldom cited as such today. In matters of land tenure, the major area of conflict is between the English concept of freehold and the customary concept of family or communal rights; and here the Islamic law is closely aligned with the English. For the rest, it is not at all difficult to design legislation acceptable to Muslim opinion to restrain that fragmentation of land holdings which so often results from the unfettered application of the Islamic law of succession. And in the more difficult question of the law of evidence and procedure, experience goes to show that here, too, Muslim opinion is prepared to accept the need to move with the times, at least outside the sphere of family relations.

The first point with which we started this paper largely resolves in practice, therefore, into the question whether a modern society can long remain viable if its legal system enshrines an interpersonal conflict of laws in the sphere of family relations and succession. And to this the answer seems to be an unequivocal affirmative. This is supported by the conclusions of a Conference on the Future of the Law in Africa which met in London in December, I959, under Lord Denning's chairmanship. ${ }^{38}$ It is also confirmed by the experience of such countries as India, Pakistan, Egypt, Lebanon, Syria, and Iraq.

It is undeniable, of course, that a bureaucratic longing for national unity, to say nothing of other pressures, will inevitably-and probably increasingly-inspire a desire for a law of family relations which is applicable to all nationals without distinction of religion; and such, for example, is the avowed objective in the Republic of India. But attempts to translate such a desire into the terms of a draft enactment (as was attempted in a White Paper on Marriage, Divorce, and Inheritance published by the Ghana government in $\mathrm{Ig} 6 \mathrm{r}$ ) do not inspire much confidence that this will prove possible-except, of course, at the expense of much offense-unless and until Muslim (and non-Muslim) opinion is prepared to accept a codification which precludes polygamy, severely restricts divorce, and abrogates the rule that there can be no inheritance between those who differ in religion. ${ }^{39}$ A desire for national unity was indeed one of the chief motives behind the promulgation of the Iraqi Code of Personal Status, I959; but it is noteworthy that this code made no attempt to do more than unify the law applicable to Sunnis and Shi'is, respectively, and that in the matter of intestate succession even this limited objective was achieved only by the drastic expedient of completely abandoning the Islamic law in favor of the statute law previously applicable to government land. ${ }^{40}$

This brings us to the second question with which we started this paper, but again

\footnotetext{
${ }^{88}$ The London Conference on the Future of Law in Africa, Record of the Proceedings. (Allott ed. 1960). See 4 J. African Law I (1960).

${ }^{30}$ As, for example, in Turkey, where the family law of Switzerland was taken over almost in toto in 1926; but a much less drastic example can also be found in the Tunisian Code of Personal Law, I956 and 1959. It is noteworthy, however, that the Ghana White Paper, quite contrary to the current tendency in the Arab world, favored giving statutory recognition to the unrestricted polygamy of the customary law-even in the case of Christians and Muslims-although only one wife could be actually registered as such.

${ }^{40}$ See Anderson, A Law of Personal Status for Iraq, 9 INT'L \& Comp. L.Q. 542 (1960).
} 
with a drastic limitation in its scope. Instead of asking whether an authoritative law, which is regarded as firmly based on divine revelation, can so adapt itself-or be adapted-as to enable it to resolve the typical conflicts of an industrial society, we must in fact pose the question whether this law can so adapt itself, or be adapted, as to enable it to conform to contemporary ideas of marriage, divorce, and succession. And the answer which comes from some of the more progressive Muslim countries seems here, again, to represent at least a qualified affirmative.

We have already seen how the Islamic law has been quietly put on one side in these countries almost completely in the sphere of criminal and commercial law, the law of evidence and procedure, and the greater part of the contents of the civil codes. In the sphere of family law and succession, on the other hand, no Muslim country other than Turkey has gone so far as this. ${ }^{41}$ Instead, Muslim countries have contrived to effect reforms in what purports (at least) to be still Islamic law by a variety of ingenious devices. One is a procedural device, by which parts of the Islamic law are simply precluded from judicial enforcement (or even recognition). Another, which has been given the widest possible application, consists in an eclectic selection of principles for which some support can be found among the heterogeneous Muslim authorities of the past, and the promulgation of these principles in the form of statute law. Yet another, which has received much less acknowledgment, represents a reinterpretation of the ancient texts in a manner more acceptable to contemporary opinion. And each of these is at times reinforced by statutory regulations which are represented as augmenting, rather than contradicting, the sacred law. ${ }^{42}$

By such devices the twin evils of child marriage and compulsory marriage have been largely remedied ${ }^{48}$ in the Arab world, although they still represent a considerable problem in some of the Commonwealth countries in East and West Africa. Polygamy, too, has been somewhat restricted in Syria, still more circumscribed in Morocco and Iraq, and completely forbidden in Tunisia. By the same means ill-used wives have been given the right to a judicial dissolution of marriage in those countries in which the ascendancy of the dominant Hanafi doctrine previously excluded any such relief. But the restriction of a husband's unfettered right to repudiate his wife at his unilateral discretion has proved far more difficult. Only in Tunisia ${ }^{44}$ has it been unequivocally enacted that a divorce pronounced outside a court of law will have no legal effect-and, even so, there is nothing to prevent a husband (or, indeed, in Tunisia a wife) from insisting on a divorce, provided he (or she) is willing to pay the financial compensation which the court may decree in favor of the injured party. ${ }^{45}$

${ }^{11}$ Except for Iraq, in so far as the law of intestate succession is concerned.

${ }^{4} \mathrm{Cf}$. J. N. D. ANDerson, IsLAMTC LAW in the MODERN WORLd (1959), and numerous articles on this subject.

${ }^{4}$ In so far, that is, as this can be achieved by legislative enactments.

"Followed, but not quite so unequivocally, by Iraq.

${ }^{25} \mathrm{Cf}$. in this context, Anderson, The Tunisian Law of Personal Status, 7 INT'L \& Comp. L.Q. 262, 267 (1958), and Anderson, The Modernization of Islamic Law in the Sudan, 5 SUDAN L.J. AND Reports $306 \mathrm{ff}$. (1960). 
This is not the place to discuss how far these reforms are based on principles which can be claimed as genuinely Islamic, or whether they must be acknowledged as not only inspired but actually borrowed from the West. It is sufficient for our present purpose that they have in fact been effected in Muslim countries and are proving, with the passage of time, ever more acceptable to Muslim opinion. Setbacks may of course occur in one country or another; but it seems overwhelmingly probable that similar reforms, at least on a limited scale, will before long extend to the countries of East and West Africa, and will little by little prepare the ground for what may one day represent a unification of the family law. There can be no doubt that such a unification would solve many problems-particularly, perhaps, in those areas where individuals frequently change their religion, or where persons of different religions intermarry. ${ }^{48}$ For the present, however, any such development seems sufficiently remote; and it can scarcely be maintained that an interpersonal conflict of laws, if confined to such matters as marriage, divorce, and succession, represents any major barrier to national advance.

\footnotetext{
"In such cases difficult problems regarding the law of inheritance which is properly applicable, or even regarding the validity of a marriage, today frequently occur. Cf. Anderson, op. cit. supra note r6, at I10-1 $8, x 25-28,137,144-46,216$.
} 